\title{
Wacław Makowski - teoretyk i praktyk polskiego autorytaryzmu, bohater dwóch poświęconych mu monografii
}

W krótkim czasie pojawiły się w obiegu naukowym dwie pozycje poświęcone Wacławowi Makowskiemu. Na początku 2014 roku w Lublinie ukazała się nakładem Wydawnictwa UMCS rozprawa habilitacyjna Grzegorza Ławnikowicza Między koniecznościa państwa a pochwała autorytaryzmu. Koncepcja państwa społecznego Wacława Makowskiego, pozycja obszerna, bo licząca 454 strony. Pod koniec 2014 roku warszawskie Wydawnictwo „Nauka i Technika" opublikowało książkę Władysława Teofila Kuleszy Państwo w myśli politycznej i ustrojowo-prawnej Wacława Makowskiego — ta pozycja liczy aż 829 stron. Warto zaznaczyć, że strona stronie nierówna; w książce W.T. Kuleszy na stronie mieści się więcej wersów, a każdy wers zawiera 98 znaków (ze spacjami), w książce G. Ławnikowicza jest ich w wersie 76. Już sama objętość książek usprawiedliwia nieco spóźnione ich omówienie, ale nie ma wątpliwości, iż obu pozycji nie sposób pominąć — z pewnością poszerzają wiedzę polskiego czytelnika o ideach politycznych, głoszonych w dwudziestoleciu międzywojennym.

Kilka słów o autorach, należy bowiem podkreślić ich kompetencję w dziedzinie historii prawa i myśli polityczno-prawnej dwudziestolecia międzywojennego. Grzegorz Ławnikowicz opublikował kilka lat temu książkę zatytułowaną Idea niezawisłości sędziowskiej w porządku prawnym i myśli prawniczej II Rzeczypospolitej (Torun 2009), ponadto jest autorem licznych opracowań poświęconych funkcjonowaniu sądownictwa międzywojennego. Władysław T. Kulesza to autor bardzo istotnej pozycji Koncepcje ideowo-polityczne obozu rzadzacego w Polsce w latach 1926-1935 (Ossolineum 1985), a spośród wielu innych publikacji przede wszystkim należy wymienić jego wstęp, wybór i opracowanie tomu $\mathrm{Wa}$ cław Makowski o państwie społecznym (Warszawa 1998). Obaj autorzy są zatem 
kompetentni do zajęcia się tematem, gdyż znają bardzo dobrze akty prawne II RP, znają też wiele źródeł, z tym, że Grzegorz Ławnikowicz koncentruje się na myśli prawnej, a Władysław T. Kulesza na myśli polityczno-prawnej.

Zarówno styl, jak i metodologia pracy omawianych autorów są całkowicie odmienne.

Grzegorz Ławnikowicz pokazuje swój warsztat, swoje rozumowanie, przede wszystkim stawia sobie pytania, a czytelnik jest świadkiem, w jaki sposób podchodzi do rozważań. Skutkuje to często zadawaniem pytań, niestety, nie zawsze opatrzonych znakiem zapytania, co chwilami jest irytującą manierą. Przykładowo, na s. 371, czytamy: „Czy w kolejnej pracy, pisanej już przecież z pewnej perspektywy i niemającej bezpośredniego politycznego celu Makowski pokusił się o doprecyzowanie swojej wizji przedstawicielstwa. Niestety nie". Osobiście nie przepadam za tego typu retoryką prac naukowych, moim zdaniem bardziej nadającą się na wykład.

Sama struktura książki Ławnikowicza jest przejrzysta i konsekwentna, oparta na wyodrębnieniu merytorycznych problemów i zagadnień, chociaż to z kolei wymagało uwzględnienia zmian poglądów i całościowego spojrzenia na twórczość Makowskiego, stąd drobiazgowa analiza i poszukiwanie spójności czy ewentualnej ewolucji poglądów. Autor najpierw przedstawia życiorys, potem zajmuje się ogólnym pojęciem państwa i państwem społecznym. Mamy tutaj merytoryczne uporządkowanie wątków. Nie ma jednak żadnej próby zdefiniowania autorytaryzmu. Jest wobec tego tak, że z jednej strony autor uważa, że Makowski wspierał system autorytarny, nawet jeśli poszczególne unormowania konstytucji kwietniowej nie były tożsame z jego poglądami czy projektami; $z$ drugiej strony jego przemyślenia naukowe i jego teoria powstania i ewolucji społeczeństwa nie zawierały niczego, co można by przeciwstawić sformułowaniom samej konstytucji i zmianom ustrojowym II Rzeczypospolitej — przeciwnie, mogły dobrze im służyć.

Podtytuły książek mogą tłumaczyć odmienne podejście do rekonstrukcji poglądów Makowskiego. Grzegorz Ławnikowicz pisze jednak o państwie społecznym, co sugeruje podtytuł „Koncepcja państwa społecznego Wacława Makowskiego”, natomiast podtytuł drugiej książki „Państwo w myśli politycznej i ustrojowo-prawnej Wacława Makowskiego" zawiera już sugestię, że autor zajmie się wszystkim, co na temat państwa miał do powiedzenia Wacław Makowski, i to nie tylko państwa jako przedmiotu badań, nie tylko polskiego, ale państwa na przestrzeni dziejów i państwa in concreto. To oczywiście daje większe możliwości, lecz także grozi niepomiernym rozszerzeniem tekstu. To najprawdopodobniej sprawiło, że W.T. Kulesza najważniejsze cytaty czy konstatacje Makowskiego wyróżnił pogrubioną czcionką.

Władysław T. Kulesza nie ma wątpliwości, że Polska w dwudziestoleciu miała system autorytarny, daje temu wyraz kilkakrotnie. I nie ma wątpliwości, że wspierał go Wacław Makowski. 
Obaj autorzy zaczynają od życiorysów. Zawsze pojawia się taki oto problem dla historyka czy badacza doktryn polityczno-prawnych: czy i w jakim stopniu życiorys jest ważny dla rozumienia treści głoszonej przez kogoś doktryny? Odpowiadając na to pytanie należy stwierdzić, że życiorys jest istotny dla rozumienia treści, które przecież jakoś nawiązują do otaczającego świata. Jeśli o filozofach można by powiedzieć, że mogą tworzyć swoje dzieła niezależnie od okoliczności, to jednak na przykład zrozumienie niechęci Platona do demokracji wiąże się z faktem, iż w demokratycznych Atenach nie mógł nawet myśleć o karierze i działalności politycznej z racji swego pochodzenia. $Z$ drugiej strony musimy skupić się na dziele, ono żyje własnym życiem i bardzo często przeżywa autora, samo stając się przedmiotem interpretacji.

Porównanie tych życiorysów jest ciekawym doświadczeniem. Już samą objętością różnią się, różnią się też szczegółowością, i to bardzo. W pracy Władysława T. Kuleszy widoczny jest temperament historyka-archiwisty: autor dotarł i wymienił listy z Jerzym, synem Makowskiego; zbadał, gdzie Makowski mieszkał, gdzie miał domek letni i w czyim sąsiedztwie, i co stoi dziś w tym miejscu, odtworzył nawet losy niektórych książek z prywatnej biblioteki Makowskiego. W książce zamieścił też sporo zdjęć, opisał także dokładnie zatrudnienia i działalność Makowskiego jako działacza politycznego, jako profesora, jego udział w kongresach naukowych; starannie też przyjrzał się jego twórczości niepolitycznej i nienaukowej, mianowicie jego recenzjom, wierszom, poematom. Można powiedzieć, że wszystko o Makowskim wie, chociaż pewnie żaden autor nie może tak twierdzić. Na przykład w książce Grzegorza Ławnikowicza jest chociażby znaleziony w archiwach — list Elizy Orzeszkowej na temat małego Wacia, do którego W.T. Kulesza nie dotarł.

Zasadniczo odmienne jednak są dalsze elementy obu książek. Mianowicie Grzegorz Ławnikowicz buduje swoją pracę według problemów, po życiorysie przedstawia w sposób usystematyzowany takie zagadnienia jak ogólne pojęcie państwa, a następnie pojęcie państwa społecznego, co do zasady książka składa się z dwóch części.

Książka Kuleszy zaś zasadniczo ma układ chronologiczny, chronologię tę opiera autor na życiu i działalności bohatera swej pracy. Prace teoretyczne Makowskiego są tylko częścią materiału badawczego. Na książkę składa się dziewięć rozdziałów, podstawą podziału są koleje życia Makowskiego. Zatem rozdział I nosi tytuł ,, Urodzony w niewoli, okuty w powiciu... ” Działalność naukowa Wacława Makowskiego przed 11 XI 1918 r., rozdział IV Między majem a Brześciem. Dziatalność W. Makowskiego w latach 1926-1930, natomiast ostatni Ostatnie lata. Obecność W. Makowskiego na szczytach sanacyjnej elity władzy w latach 1938-1939. Ponad 100 stron zawierają Uwagi końcowe, wśród których znalazł się obszerny wywód na temat pojęcia autorytaryzmu i systemów autorytarnych. Przyjąwszy taki układ chronologiczny, autor siłą rzeczy musi się powtarzać. Prosty przykład: Makowski uważał, że podział władzy według Monteskiusza 
to przeżytek. Właściwie głosił od początku swojej twórczości naukowej i powracał do tej myśli w wielu swoich artykułach i przemówieniach. Co je różniło, to kontekst polityczny. I za każdym razem autor streszcza te przemówienia, mówiąc, że Makowski zaczął od tradycyjnego etc. Może jednak praca z zakresu historii doktryn powinna przynosić jakieś podsumowania, wskazać na konsekwencje danego rozumowania, a nie skupiać się na drobnych niuansach w wypowiedziach Makowskiego, które często wynikały z ostrożności politycznej. Z drugiej strony u Kuleszy bardzo dobrze - właśnie z powodu tego układu — wyróżniona jest pewna ewolucja poglądów Makowskiego, widoczna na przykład w pojmowaniu narodu i włączeniu jego rozumienia etnicznego po powstaniu OZN. Myślę jednak, że za dużo w tej książce omówień i szczegółowych danych z zakresu kalendarium obrad Sejmu. Na przykład sądzę, że nie było absolutnie konieczne tak szczegółowe analizowanie sposobu prowadzenia obrad Sejmu, Senatu czy komisji parlamentarnych i na zagęszczonych stronach pokazywanie sposobu prowadzenia obrad i zwischenrufów parlamentarzystów. Sama analiza przemówienia z dnia 22 stycznia 1929, kiedy to Makowski jako poseł BBWR argumentował na rzecz rewizji konstytucji marcowej, zajmuje kilka stron (s. 288-296). Szczegółowość informacji nie sprzyja jej syntetyzowaniu.

A jednak z obu książek wyłania się pewna synteza. Obaj autorzy są zgodni, że Makowski był przedstawicielem realistycznej, opartej na socjologii i psychologii, teorii państwa i prawa. Obaj wskazują, iż wykorzystał dorobek szkoły francuskiej, przede wszystkim takich autorów jak Leon Duguit. Lista nazwisk podawanych przez obu autorów jest o wiele dłuższa, oprócz Leona Petrażyckiego wymieniany jest L. Durkheim, M. Hariou, C. Bouglé, G. Gurvich, P. Léon (np. Ławnikowicz, s. 203; Kulesza, s. 418-419).

Najważniejszym elementem w myśleniu Makowskiego było stwierdzenie, że państwo jest zrzeszeniem celowym, odmiennym od wszystkich innych. Ciekawe jest też jego pojęcie władzy, oparte na stosunku władzy, który to stosunek nie jest kwestią przewagi siły i przemocy, raczej wynika z psychiki ludzkiej. Zrzeszenie celowe oznacza, że ktoś musi społeczeństwu przewodzić. Powiedziałabym, że to ostatnie to banał, jeśli odrzuca się umowę społeczną jako wizję genezy państwa. Wcale mnie nie dziwi - i Arystoteles, i św. Tomasz z Akwinu, i wielu innych twierdziło, że człowiek jest z natury zwierzęciem społecznym. Makowski daje w swoim dziele bardzo staranny wykład o tym, co jest podstawą istnienia państwa. Rzeczywiście, z obu książek wyłania się oryginalna teoria ewolucji społeczności ludzkiej i pojawienia się państwa oraz przekonanie Makowskiego, że celem państwa jest dojście do państwa społecznego, opartego na solidaryzmie. Ale problem zaczyna się od pytania, po co ludzie żyją w państwie: czy po to i dlatego, że umożliwia im ono przetrwanie i rozwój, czy też po to, by było ono trwałe, dobre, wielkie?

Tutaj bardzo pogłębioną analizę daje Grzegorz Ławnikowicz. Bardzo dokładnie i w jednym miejscu — mianowicie w I części swej książki rekonstruuje rozważania Makowskiego, co prowadzi do pewnej syntezy. Najkrócej rzecz ujmując, 
Makowski zajmował się najpierw fenomenem życia w społeczności. To, że jest ono konieczne, że człowiek jest istotą społeczną, było dla Makowskiego pewnikiem (Ławnikowicz, s. 96-97). Następnie stwierdza, że te formy życia społecznego przybierają formę państwa, a ewolucja zmierza ku państwu społecznemu.

Państwo jest koniecznym i naturalnym, na solidarności i zależności wzajemnej opartym zespoleniem obywatelskim; celem państwa jest organizacja współpracy obywatelskiej dla zaspokojenia potrzeb zbiorowego życia, dla urzeczywistnienia ładu prawnego, rozszerzenia i udoskonalenia życia i jego warunków. Czynność pozytywna tego zespolenia obywatelskiego polega na zużytkowaniu dla zbiorowego celu pracy i uzdolnień człowieka, na udzieleniu człowiekowi pomocy i opieki zbiorowej — oto definicja (Ławnikowicz, s. 256). Państwo społeczne ma realizować zasadę solidarności i solidaryzmu, zaś ,,[s]olidaryzm pragnąłby postawić na miejsce solidarności obiektywnej, nieświadomej i niezależnej od człowieka, solidarność subiektywną, świadomą i umowną" (Kulesza, s. 405). Makowski z całą mocą odrzuca ideę, iż państwo jest dla ochrony praw człowieka — na przykład prawa do życia, do wolności i do własności. Państwo jest czymś więcej, ma być czymś więcej, ma zagwarantować solidaryzm społeczny, wspólnotę. Ma być państwem społecznym. Otóż ważne jest to rozumienie państwa społecznego.

Najbardziej zdumiewa, że Makowski stanowczo odrzuca właśnie ów liberalizm i ideę praw człowieka, opierając wspólnotę tak naprawdę na pracy jednostki dla dobra społeczności. Czy do tego konieczne jest zespolenie dusz? - co zdaje się jednak wynikać z wypowiedzi politycznych Makowskiego. I czy solidaryzm wyklucza demokrację i podział władzy? Makowski uważał, że stary liberalizm kompletnie się zużył. Notabene, w ujęciu Makowskiego, państwo prawne to państwo libertariańskie, a przecież to nie jest adekwatne rozumienie i współcześnie z pewnością za państwo prawne uważa się także państwa o wysokim poziomie interwencjonizmu. Makowski nie jest tutaj ani sprawiedliwy, ani wnikliwy, kiedy pisze, że te negatywne gwarancje aprobowały wyłącznie egoizm i ochronę praw podmiotowych i że do tego sprowadza się pojęcie państwa prawnego. Zawsze mnie zastanawia, dlaczego współcześni tak mało pamiętają, iż sławny artykuł siedemnasty Deklaracji Praw Człowieka i Obywatela z 1789 roku zawierał dwa zdania, nie tylko o świętej i nienaruszalnej własności. Zdanie drugie przecież głosiło możliwość wywłaszczenia, „gdy tego wymaga w sposób oczywisty konieczność publiczna uznana przez prawo, wszelako pod warunkiem słusznego

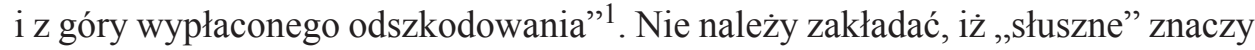
tyle, co „niebotyczne”. Ponadto można zauważyć, że zwiększony interwencjonizm państwa, dopuszczenie do kontroli umów o pracę, wprowadzenie negocjacji w sprawie tzw. wages boards w Anglii miał miejsce już na początku XX wieku i państwa europejskie powoli przestawały ograniczać się do roli stróża nocnego.

${ }^{1}$ Cyt. J. Justyński, Wybór tekstów źródłowych z historii doktryn polityczno-prawnych, Toruń 1994, s. 111. 
Jednak nie wynika z tego logiczna konieczność rezygnacji z demokratycznych rządów prawa. Argument, że trójpodział władzy nie odpowiada państwu interweniującemu, jest nierzetelny. Rezygnowanie z trójpodziału władzy, jego niezwykle ostra krytyka u Makowskiego wynikają moim zdaniem nie z logiki wywodu, lecz bardziej z rozczarowania polską demokracją, z chęci dostarczenia argumentów politycznych obozowi rządzącemu i Komendantowi.

Rozumowanie Makowskiego, ciągle zresztą powtarzane, zarówno w pracach naukowych, jak i w przemówieniach politycznych, było następujące: od końca XIX wieku państwo przestało spełniać już tylko funkcję stróża nocnego, i temu rozumowaniu nie można zarzucić błędu. Tak było, Makowski wielokrotnie wraca do przykładu New Dealu, do Francji, pokazuje zresztą jako alternatywę także inne państwa, jak Rosja czy Włochy.

W obu książkach zabrakło mi jednak krytycznego kontrargumentu, mianowicie, że można było oprzeć i pogodzić element praw jednostki i solidaryzmu; przypomnijmy, że tzw. liberałowie społeczni, jak Hobhouse czy nawet w pewnych momentach J.S. Mill uważali, że prawa człowieka, a przede wszystkim wolność jednostki, musi być faktyczną wolnością i równością, co było widoczne szczególnie u Hobhouse'a ${ }^{2}$. Także Woodrow Wilson apelujący o nową wolność nie uważał, że należy zmieniać zasady demokracji w Ameryce i nie kwestionował podziału władzy ${ }^{3}$.

Z faktu, że państwo spełnia inne i szersze zadania, co przyzna każdy realista, nie wynika też wcale, iż musi być niedemokratyczne. Nie ulega wątpliwości, że demokracja była jednym z najbardziej krytykowanych pojęć u Makowskiego. Demokracja to przecież dyskusja, debata, pluralizm. Makowski marzył o państwie, które wszystkich zespala, wszystkich łączy. Demokracja to jednak kompromis, chociaż oparty na niewzruszalnych zasadach. $Z$ tego punktu widzenia lepiej niż nieokreślona zasada solidaryzmu służy jednak opracowanie granicy, poza którą demokracja i solidaryzm nie mogą wykroczyć, i tak chyba dziś rozumie się państwo prawa. Moim zdaniem pogodzenie praw człowieka $\mathrm{z}$ interwencjonizmem jest czasami trudne, ale jest to jedyna właściwa metoda postępowania, w przeciwnym razie, w imię wspólnego dobra czy dobra powszechnego, może zdarzyć się wiele złych rzeczy. W komentarzach autorów zabrakło mi właśnie tego wątku. Myślę też, że jeżeli zajmujemy się ideą państwa solidarystycznego, to warto popatrzeć na konsekwencje współczesne, a w omawianych książkach za mało widać odniesień krytycznych, szczególnie u Grzegorza Ławnikowicza. Władysław T. Kulesza nie stroni od nich, na przykład kiedy wyraźnie pisze, że poglądy Makowskiego na temat elit są zdecydowanie sprzeczne ze współczesnym pojmowaniem demokracji.

2 Por. M. Zmierczak, Leonard Trelawney Hobhouse - prekursor liberalizmu spolecznego, „Gdańskie Studia Prawnicze” 2009, t. XX, Studia z zakresu myśli politycznej i prawnej s. 437-452.

${ }^{3}$ Zob. W. Wilson, Nowa wolność, [w:] B. Sobolewska, M. Sobolewski, Myśl polityczna XIX i XX w. Liberalizm, Warszawa 1978, s. 419-427. 
Natomiast jest faktem, że lektura obu książek, a już szczególnie W.T. Kuleszy, pokazuje jedno: w XX wieku termin „demokracja” miał pozytywne znaczenie i pozytywną konotację. Toteż wszyscy przeciwnicy i krytycy demokracji zawsze starali się pokazać, iż oni właśnie są za prawdziwą demokracją, że demokracja to nie mogą być rządy motłochu, demokracja jest do pogodzenia z elitaryzmem, demokracja „prawdziwa” musi być oparta na wartościach etc. Właśnie Makowski doskonale reprezentuje ten typ myślenia, który zresztą występuje u wszystkich innych, również bardzo odległych od Makowskiego, jej przeciwników - Hitler nader chętnie mówił o prawdziwej germańskiej demokracji, zaś Lenin o demokracji proletariackiej.

Oczywiście w obu książkach pojawia się wątek autorytaryzmu, to znaczy teza, że Makowski wspierał system autorytarny. Bardzo wiele miejsca poświęcił kwestii pojęcia autorytaryzmu Władysław Kulesza, dał opis europejskich państw autorytarnych, wskazał na ich elementy wspólne i rozbieżne. Jeżeli czegoś mi zabrakło, to jednego z wątków: badacze totalitaryzmów często wskazują, iż totalitaryzm żąda od jednostki stałej mobilizacji i stałego wskazywania na lojalność, podczas gdy autorytaryzm koncentruje się na posłuszeństwie. Makowski sytuuje się jakby pośrodku, bo jednak chciałby — to widać z jego wielu tekstów — tego obywatelskiego uniesienia, élan, poświęcenia dla dobra wspólnego. Oczywiście przyjęcie, że autorytaryzm to przewaga władzy wykonawczej nad prawodawczą, jest chyba już dość popularne, ale Makowski pisał nie tylko o tym aspekcie. W rozważaniach nad istotą autorytaryzmu pewien niedosyt może wzbudzić bezsporne zaliczenie Włoch do państw totalitarnych. Wielu badaczy wyraźnie się od tego odżegnuje, wskazując bardziej na „totalitarny potencjał” niż na rzeczywistość. W każdym razie przy tylu komentarzach wymagałoby to omówienia ${ }^{4}$.

Powiedziałabym na koniec tak: otrzymaliśmy obszerne analizy pokazujące jeden z typów myśli politycznej, teorii, filozofii, nadający się do uzasadnienia państwa, w którym nie ma równości praw politycznych ani wolności słowa, ani swobód obywatelskich. Jest to uzasadnienie rodzime, wyrosłe w społeczeństwie polskim. Cóż, świadczy to tylko o tym, że takie myślenie było popularne i jak bardzo subtelnie można operować pojęciem solidaryzmu i ideałem państwa społecznego, aby przede wszystkim usprawiedliwić ograniczenie wpływu obywateli na władzę. Takie idee pojawiają się i będą się pojawiać, zmieniające się okoliczności powodują często zmianę argumentacji. Jednakże ujęcie i sprowadzenie argumentacji do hasła „solidaryzmu i solidarności” wydaje mi się zabiegiem nieuprawnionym. Pojęcie solidarności, używane przez bardzo różnych myślicieli, nie jest koniecznie kojarzone z jakimś ustrojem. Skoro już pamiętamy, że

${ }^{4}$ Zob. na ten temat M. Flores, History and memory: the perception of totalitarianism in Italy in a comparative perspective, [w:] Totalitarian and Authoritarian Regimes in Europe. Legacies and Lessons from the Twentieth Century, red. J.W. Borejsza, K. Ziemer, New York-Oxford 2006, s. 70-79 oraz J. Petersen, The concept of totalitarianism in Italian culture after 1945, [w:] Totalitarian and Authoritarian..., s. 541-555. 
solidaryzm klasowy i współpraca klas była wymieniana przez Leona XIII, to warto jednak pamiętać, iż ten papież, choć pośrednio, jednak pogodził się z demokracją, podobnie jak Jan XXIII czy Jan Paweł II. Analiza treści dzieła Wacława Makowskiego nie może sprowadzać się do hasła „solidaryzm społeczny”, bo to pojęcie, któremu różni autorzy i różne doktryny nadały rozmaitą i niekiedy bardzo rozbieżną treść. Studiujemy idee polityczne także po to, żeby wyraźnie widzieć różnice i podobieństwa we współczesnych ideach politycznych.

Nie należy też przyjmować za dobrą monetę wszystkich podobieństwa słów i terminologii samego Makowskiego. To, że powołuje się on czy próbuje pokazać, że Komendant (wódz) ma mieć pozycję nadrzędną i sytuuje go w roli pouvoir intermediaire, wcale nie świadczy o poglądach Benjamina Constanta (W.T. Kulesza, s. 316). Jeżeli uważnie czyta się Constanta, to z jednej strony chce on dodać królowi majestatu, z drugiej zaś odebrać mu władzę, przystosować i tak skonstruować ustrój, aby oktrojowana Karta konstytucyjna z 1814 roku dała się pogodzić z monarchią, lecz nie po to, by rzeczywiście królowi dać pierwszeństwo. Król był jedną z sześciu władz, suwerenność spoczywała w narodzie, a władza neutralna właśnie jest niezdolna do rządzenia, bo „[w]ładza neutralna to autorytet bez prawa do czynnego działania"5.

Drugi element to problem narodu albo źródła władzy. Tutaj w istocie autorytaryzm Makowskiego idzie w parze z uznaniem, że naród to obywatele, bez względu na ich etniczne pochodzenie czy wyznawaną wiarę. To oczywiście różniło piłsudczyków od narodowej demokracji, która jednak bazowała na jedności tradycji, pochodzenia i wiary. Rzecz jasna, w warunkach Polski międzywojennej trudno byłoby przyjąć takie założenie. $\mathrm{Z}$ drugiej jednak strony Władysław T. Kulesza pokazuje wyraźnie, iż rzeczywistość polityczna skłoniła i Makowskiego do pewnej zmiany poglądów.

Nie śmiałabym twierdzić, że jedna z tych książek jest lepsza czy gorsza. Są zupełnie inne. Dla badacza doktryn z pewnością bardziej przyswajalna jest książka Grzegorza Ławnikowicza; dla historyka ustroju, badacza konstytucjonalizmu, bardziej interesująca jest i będzie książka Władysława T. Kuleszy, który poświęca wiele miejsca „kuchni redakcyjnej” noweli sierpniowej czy konstytucji kwietniowej, działalności sejmowej, walce o wpływy wśród piłsudczyków etc. Do pewnego stopnia, ze względu na szczegółowe streszczenia i liczne cytaty, książka ta może być wykorzystywana jako przewodnik po źródłach (mamy na przykład dokładne informacje o tym, iż nie istnieje fizycznie protokół z ostatniego posiedzenia sejmu, mamy dokładne informacje o różnych wariantach niektórych przemówień). Ale czasami bywa tak, że od przybytku głowa boli, czasami też sympatia do obiektu badań skłania autora do pewnej przesady. Mam na przykład wątpliwości, czy można uznać, że Makowski był pierwszym sowietologiem polskim?

5 Zob. trafną analizę u W. Szyszkowskiego, Beniamin Constant. Doktryna polityczno-prawna na tle epoki, Warszawa-Poznań-Toruń 1984, s. 86-92. 
I czy był pionierem w dziedzinie analizy zjawiska marketingu politycznego czy reklamy politycznej? Jest prawdą, że trafnie wskazał na rolę reklamy politycznej, ale wówczas nie był ani pierwszy, ani z tego powodu znany.

Moja ostatnia - i niestety bardzo krytyczna - uwaga dotyczy pracy redaktorów wydawnictwa. W książce Władysława T. Kuleszy nieliczne są strony, w których występują „ogonki” czy też kropki, bardzo często jest ,juz” zamiast ,już”, co zmusza czytelnika do zastanawiania się, czy chodzi o mianownik, czy biernik. Jest tego naprawdę bardzo dużo, przykładowo strony 275, 277, 635; na pozostałych rzadkością jest poprawność wszystkich ,ą" i „,e”. Szkoda! I moim zdaniem, nie mamy słowa „represywność” tylko „represyjność”, tak samo jak „represyjny”, a nie „represywny” (s. 743-744) ${ }^{6}$, zaś słowo „ansa” jest rodzaju żeńskiego, więc nie ,ansów” (s. 760), lecz ,ans” jest poprawną formą ${ }^{7}$. Kolejne pytanie dotyczy pisania tytułów, które składają się z wielu elementów. Moim zdaniem trzeba dawać kropki, nawet jeśli ich nie ma na karcie tytułowej, bo przecież zestawienia takie, jak „Państwo stanu wyjątkowego Rzecz o systemie państwa i prawa w III Rzeszy" nie są czytelne. No i oczywiście, nie było w rządzie międzywojennym żadnego ministra I. Nowaka (s. 122) i nie był również to Juliusz Nowak (s. 826). To wina braku korekty, gdyż na s. 34 — prawidłowo — jest mowa o Julianie Nowaku. Z kolei w książce Grzegorza Ławnikowicza irytujące jest niestawianie znaków zapytania w często stosowanych pytaniach retorycznych, które mają wskazać czytelnikowi wątpliwości autora czy też naprowadzać na tok rozumowania.

Ostatnia uwaga jest następująca: czy to dobrze, czy źle, że powstały książki naukowe, obie napisane $\mathrm{z}$ wielkim nakładem pracy, obie poświęcone nietuzinkowej postaci dwudziestolecia międzywojennego, jaką niewątpliwie był Wacław Makowski i obie ukazały się niemal równocześnie? Władysław T. Kulesza pisze, że książka Grzegorza Ławnikowicza ukazała się już po oddaniu jego dzieła do druku, odnotowuje to w dorzuconym, zaznaczonym gwiazdką przypisie. Ławnikowicz z kolei w przypisach daje relatywnie mało odwołań do obszernej i obfitej twórczości Kuleszy, który jednak jest wybitnym znawcą polskiej myśli politycznej dwudziestolecia międzywojennego. Pytanie, czy nie ma komunikacji między znawcami doktryn polityczno-prawnych, czy też może nie czytamy nawzajem swoich prac, nie orientujemy się, kto czym się zajmuje? Bez względu na przyczyny, takie zjawisko powinno niepokoić, a w każdym razie skłaniać do krytycznej refleksji, bo przecież jest jeszcze wiele tematów nieobjętych badaniami - także w zakresie polskiej myśli politycznej.

${ }^{6}$ Zob. Uniwersalny słownik języka polskiego, t. P-Ś, Wyd. Naukowe PWN, Warszawa 2006, s. 932 .

7 Ibidem, t. A-J, s. 89. 


\section{Bibliografia}

Flores M., History and Memory: the perception of totalitarianism in Italy in a comparative perspective, [w:] Totalitarian and Authoritarian Regimes in Europe. Legacies and Lesson from the Twentieth Century, red. J.W. Borejsza, K. Ziemer, New York-Oxford 2006.

Kulesza W.T., Państwo w myśli politycznej i prawno-ustrojowej Wacława Makowskiego, Warszawa 2014.

Ławnikowicz G., Między koniecznościa państwa a pochwała autorytaryzmu. Koncepcja państwa społecznego Wactawa Makowskiego, Lublin 2014.

Petersen J., The concept of totalitarianism in Italian culture after 1945, [w:] Totalitarian and Authoritarian Regimes in Europe. Legacies and Lesson from the Twentieth Century, red. J.W. Borejsza, K. Ziemer, New York-Oxford 2006.

Sobolewska B., Sobolewski M., Myśl polityczna XIX i XX wieku. Liberalizm, Warszawa 1978.

Szyszkowski W., Beniamin Constant. Doktryna polityczno-prawna na tle epoki, Warszawa-Poznań-Toruń 1984.

Totalitarian and Authoritarian Regimes in Europe. Legacies and Lesson from the Twentieth Century, red. J.W. Borejsza, K. Ziemer, New York-Oxford 2006.

Zmierczak M., Leonard Trelawney Hobhouse - prekursor liberalizmu społecznego, „Gdańskie Studia Prawnicze" 2009, t. XX, Studia z zakresu myśli politycznej i prawnej.

\section{WACŁAW MAKOWSKI - A THEORIST AND PRACTITIONER OF POLISH AUTHORITARIANISM, PROTAGONIST OF TWO MONOGRAPHS}

\section{Summary}

The article is an extensive discussion and comparison of books published by two authors in 2014, Grzegorz Ławnikowicz and Władysław T. Kulesza, devoted to the same figure from the interwar period, Wacław Makowski. They present the political ideas of Makowski, a theorist of the state, who created a concept of social state, a state based on the solidarity principle, and, at the same time, was an opponent of liberal democracy based on the protection of human rights. Apart from bringing Makowski back from obscurity, the present author shows first of all how different two books on the same topic can be, a difference stemming from the research methodology applied, but probably also from the personality of the two authors. A rhetorical question remains whether the fact that two scholars explore the same topic for quite a while reflects well on communication between research centres in Poland.

Keywords: authoritarianism, Second Polish Republic, constitution, democracy, Sanacja regime.

Maria Zmierczak

mariaz@amu.edu.pl 